Rua Ramos Ferreira, n. 199 - condomínio Vista Del Rio

Bloco Solimões - apto. 704 69010-120 - Manaus - Amazonas

E-mail: almirdcjr@yahoo.com.br

\section{ÍNDIOS CRISTÃOS \\ NO COTIDIANO \\ DAS COLÔNIAS DO \\ NORTE \\ (SÉCULOS XVII E XVIII)}

Almir Diniz de Carvalho Júnior

Universidade Federal do Amazonas

\title{
Resumo
}

Este artigo pretende apresentar obscuros personagens, nomeados de índios cristãos, que, na historiografia mais tradicional, ficaram submersos nas narrativas. Pretende mergulhar nos meandros do cotidiano do antigo Estado do Grão-Pará durante os séculos XVII e XVIII, através principalmente da retórica jesuítica, e, neste microcosmo das ações cotidianas, encontrar algumas dessas vítimas do esquecimento.

\section{Palavras-chave}

Índios cristãos - história colonial da Amazônia - história indígena. 


\title{
CHRISTIANS INDIANS \\ IN EVERYDAY LIFE \\ OF THE NORTH \\ COLONIES \\ (SEVENTEENTH AND \\ EIGHTEENTH CENTURIES)
}

Contact

Rua Ramos Ferreira, n. 199 - condomínio Vista Del Rio

Bloco Solimões - apto. 704 69010-120 - Manaus - Amazonas

E-mail: almirdcjr@yahoo.com.br

\author{
Almir Diniz de Carvalho Júnior \\ Universidade Federal do Amazonas
}

\begin{abstract}
This article intends to show obscure actors, named Christians Indians, who, in the traditional historiography, were submerged in the narratives. Likewise, this one intends to dive in the everyday life of the old Grão-Pará State, during the Seventeenth and Eighteenth centuries, principally through the rhetorics of the Jesuits and to find some victims of that forgetfulness in microcosm of those everyday life actions.
\end{abstract}

\section{Keywords}

Christian Indians - Amazon colonial history - Indian history. 
Entre meados do século XVII e primeira metade do século XVIII, no norte da América portuguesa, inúmeros ameríndios foram convertidos ao cristianismo. Dois jesuítas, com quase um século de distância um do outro, relataram em suas crônicas a experiência desse processo de conversão. $\mathrm{O}$ primeiro chamava-se João Felipe Bettendorff. Ele era de origem germânica e foi escolhido pelo padre Antônio Vieira para participar da missão naquela região, então conhecida como Maranhão. A Companhia de Jesus ali se instalara algumas décadas antes, sob a proteção da Coroa lusitana. ${ }^{1}$ O outro jesuíta chamava-se João Daniel e foi missionário durante o final da primeira metade do século XVIII, num momento completamente diverso do anterior. A missão jesuítica na região havia sido extinta. O lugar era o mesmo, mas o nome mudara, chamava-se agora Grão-Pará e Maranhão. Além do nome, outras coisas mudaram e o relato de João Daniel foi escrito numa obscura prisão em Portugal, na qual se encontrava preso por determinação do marquês de Pombal. ${ }^{2}$

Com quase cem anos de diferença, os dois textos se complementam e demonstram características muito peculiares daqueles novos convertidos. Centenas de homens, mulheres e crianças, deslocados de seus lugares de origem, passaram a habitar os espaços que o Ocidente criou: aldeias missionárias, fazendas, vilas e cidades. Eles eram índios cristãos e passaram a ocupar um lugar naquele novo mundo colonial.

\footnotetext{
1 Johann Philipp Bettendorff nasceu em Lintgen, Luxemburgo, em 25 de agosto de 1626. Chegou ao Maranhão em janeiro de 1661 e, durante 38 anos, viveu e foi missionário naquele estado. Já no fim de sua vida, atendendo a um pedido dos superiores da missão, começou a escrever sua crônica. Provavelmente, ela terminou de ser escrita em 1698, ano da provável morte de seu autor. A crônica de Bettendorff veio a público pelas mãos de Antônio Gonçalves Dias (18231864) que encontrou uma cópia do original na Torre do Tombo em Lisboa. Dessa cópia, fez-se uma edição pela Imprensa Nacional em 1910, tendo sido reeditada em edição fac-similar, em 1990, pela Secretaria de Cultura do Estado do Pará: BETTENDORFF, João Felipe. Crônica dos padres da Companhia de Jesus no Estado do Maranhão. Belém: Secult, 1990 (versão aqui utilizada) [1910].

2 João Daniel era português e viveu na Amazônia entre os anos de 1741 e 1757. A mando do marquês de Pombal, foi preso e enviado ao cárcere em Lisboa onde ficou durante dezoito anos, entre 1757 e 1783, até sua morte. Tudo indica que tenha escrito o Tesouro descoberto no máximo rio Amazonas no seu período de cárcere. Depois de sua morte, parte do texto, na forma de códice, foi guardada na Biblioteca Real. Foi trazido para o Brasil em 1808 por d. João VI. Este códice está depositado nos acervos da Biblioteca Nacional do Rio de Janeiro desde 1810. A obra foi dividida em seis partes. A sexta parte perdeu-se, mas foi reencontrada na Biblioteca de Évora, em Portugal. Finalmente, foi incorporada aos acervos da Biblioteca Nacional do Rio de Janeiro. Em 1976, a obra completa foi publicada em separata dos Anais da Biblioteca Nacional, versão aqui utilizada: DANIEL, João. Tesouro descoberto no rio Amazonas. Rio de Janeiro: Biblioteca Nacional, 1976. (Separata dos Anais, tomo I) [1810].
} 
Este trabalho se inscreve na abordagem chamada de nova história indígena. Nas últimas décadas do século XX, no continente americano e no Brasil, um novo olhar sobre a história indígena foi sendo aos poucos produzido. Na década de 1970, a historiadora americana Karen Spalding, seguindo essa tendência, cunhou o termo "índio colonial" apresentando uma nova perspectiva que colocava em evidência o papel dos atores ameríndios no contexto do mundo colonial americano. O termo "índio colonial" tentou dar conta de etnias diversas cujos integrantes, mesmo convivendo com o mundo colonial durante gerações, continuavam sendo identificados como índios pelos brancos, embora não mais vivessem em suas comunidades de origem. Distanciados física e culturalmente de suas raízes, ainda mantinham traços, tradições e práticas que os diferenciavam do mundo branco e negro com o qual conviviam. ${ }^{3}$

A nomeação de índios cristãos deriva-se da de índios coloniais. Eles também se enquadravam numa chave identitária genérica, porém com fronteiras mais bem definidas. Somente os batizados poderiam ser cristãos: deveriam conhecer a doutrina, respeitar os sacramentos, tomar nomes portugueses e ser objeto de uma reforma moral - mas continuavam índios. Compunham-se de etnias diversas em sua origem, mas definiam um tipo de inserção social particular que gerava, por parte da legislação portuguesa, um lugar normativo específico. ${ }^{4}$ Este artigo pretende apresentar alguns destes atores que, na historiografia mais tradicional, ficaram submersos nas

\footnotetext{
SAPALDING, Karen, The colonial Indian: Past and future research perspectives. Latin American Research Review, 7, n. 1, 1972, p. 47-76. Sobre a "nova história indígena" e para um ótimo panorama dos novos trabalhos que tomaram por foco a história indígena na América e no Brasil a partir da década de 1970, ver: MONTEIRO, John Manuel. Tupi, Tapuias e historiadores: estudo de história indígena e do indigenismo. Tese de livre docência, Unicamp, Campinas, 2001, p. 01-11. É também deste autor um dos trabalhos pioneiros sobre o protagonismo indígena na nova historiografia colonial, particularmente na historiografia paulista: MONTEIRO, John Manuel. Negros da terra - índios e bandeirantes na origem de São Paulo. São Paulo: Companhia das Letras, 1994. Outra importante obra que inspirou novas leituras sobre os processos de apropriação e ressignificação da religiosidade cristã por parte de índios e mamelucos no período colonial foi: VAINFAS, Ronaldo. A heresia dos índios-Catolicismo e rebeldia no Brasil colonial. São Paulo: Companhia das Letras, 1995. O autor demonstrou a importância das fontes inquisitoriais para o estudo desta temática. Outra fundamental obra que congregou boa parte dos textos de antropólogos e historiadores que se dedicavam à história dos índios foi o livro organizado por CARNEIRO DA CUNHA, Manuela (org.). História dos índios no Brasil. São Paulo: Companhia das Letras, 1992.

${ }^{4}$ Sobre a legislação indigenista portuguesa e sobre as relações de poder estabelecidas nas colônias do norte da América lusitana, ver: DOMINGUES, Ângela. Quando os índios eram vassalos: Colonização e relações de poder no norte do Brasil na segunda metade do séc. XVIII. Lisboa: Comissão Nacional para as Comemorações dos Descobrimentos Portugueses, 2000. Outro importante estudo analisa os princípios da legislação indigenista na Colônia: PERRONE-MOISÉS, Beatriz. Índios livres
} 
narrativas. Pretende buscá-los no microcosmo das suas ações cotidianas, através da retórica dos dois jesuítas. ${ }^{5}$

Do ponto de vista do enquadramento teórico para a análise dessas populações, para além das perspectivas estruturalistas e do seu contraponto mais tradicional - menos sincrônica e mais voltada para a importância dos contatos interétnicos -, esta análise utiliza como inspiração as ideias de Marshall Sahlins, para quem a dimensão dos padrões culturais, dos processos identitários e da política indígena partem de uma perspectiva mais dinâmica, mas não desmerecem seus pontos de conexão estruturais. ${ }^{6}$

Sob um diapasão mais sensível, diversos trabalhos, nos quais incluo este, fizeram uma leitura mais cuidadosa das fontes demonstrando que o protagonismo dos conquistadores deveria dividir espaço com uma persistente agência ameríndia. Antigos arquivos e velhas fontes foram revisitados e os fantasmas de personagens indígenas antes invisíveis tomaram corpo. Eles passaram a gritar sua presença nos documentos oficiais, nas crônicas dos funcionários da Coroa portuguesa, nos relatos de viajantes e missionários, nos processos da inquisição, entre outros. ${ }^{7}$

Uma das questões centrais com que se deparou esta e outras análises corresponde ao problema das identidades sociais e étnicas. Como era possível eleger atores indígenas no contexto de sua ocidentalização sem retirar

e índios escravos: os princípios da legislação indigenista do período colonial (séculos XVI e XVIII). In: CARNEIRO DA CUNHA, Manuela (org.), op. cit., 1992.

5 Para uma discussão mais pormenorizada sobre esse enquadramento identitário, ver: CARVALHO JÚNIOR, Almir Diniz de. Índios cristãos - a conversão dos gentios na Amazônia portuguesa (1653-1769). Tese de doutorado, Unicamp, Campinas, 2005.

6 SAHLINS,Marshall. Ilhas de história. Rio deJaneiro:Zahar, 1990. Sobre as escolhas teóricas, principalmente dos antropólogos que se dedicaram à história indígena, ver:MONTEIRO, John, op. cit,, 2001, p.01-11.

7 Um exemplo de um olhar mais apurado direcionado às fontes, visando enxergar o protagonismo indígena para a mesma região, é o trabalho de Patrícia Sampaio que analisa o contexto da implantação da Carta Régia de 1798, legislação que substituiu o Diretório pombalino de 1757, diante das estratégias políticas das lideranças indígenas. Com a implantação da lei, houve uma mudança no controle dos trabalhadores indígenas: passaram a ser geridos pelas câmaras das vilas, não mais pelos antigos diretores e pelos seus principais (como rezava o Diretório dos Índios). No entanto, muitos oficiais das câmaras eram índios e boa parte dos militares escolhidos por elas para liderar os corpos de milícias (agrupamentos nos quais estes índios foram divididos) também o eram. Portanto, o que poderia, a princípio, ser uma estratégia para implantar o controle do Estado sobre esses novos vassalos, sofreu o impacto, mais uma vez, de um processo de negociação política com os indígenas que não deixaram de ser sujeitos políticos, mesmo já tão tardiamente. SAMPAIO, Patrícia Maria Melo. "Vossa Excelência mandará o que for servido...": políticas indígenas e indigenistas na Amazônia portuguesa do final do século XVIII. Revista Tempo. Rio de Janeiro: Departamento de História - UFF, vol. 12, n. 23, 2007, p. 49-65. 
deles sua razão de existir, seus marcadores de identidade? Era então necessário repensar esses padrões, partindo de um pressuposto básico: identidades não são fixas, elas são construções históricas. Era também necessário ter em mente que tais marcadores criavam um sentido social compartilhado - se não eram rígidos também não poderiam ser totalmente voláteis - gerando "etnocídios" e consequente aculturação. Partindo de uma perspectiva dialógica entre as definições endógenas e exógenas, esta análise pensa as identidades como marcadores que se articulam no contexto dinâmico da vida social, criando novos sentidos e novas redes de solidariedade. ${ }^{8}$

A ideia de que as sociedades nativas estavam em inexorável extinção perdeu lugar para o estudo do sentido de sua transformação. Um dos conceitos que foram amplamente utilizados por boa parte dos autores que se dedicaram a estudar as populações indígenas no contexto de sua inserção no mundo ocidental foi o de etnogênese. John Monteiro considera a visão defendida por Jonathan Hill sobre este conceito como a mais adequada. Segundo Hill, além da autodefinição dessas populações passar pelo seu patrimônio social, cultural e linguístico, elas utilizariam certas estratégias que criariam e/ou renovariam identidades duradouras num contexto mais amplo de descontinuidades e de mudanças radicais. Hill também observa que essas populações, para manterem a sua existência diante de mudanças muitas vezes radicais, utilizavam-se da etnogênese como resposta também para seus conflitos internos com outros povos indígenas e com afro-americanos.

\footnotetext{
${ }_{8}^{8}$ Sigo a perspectiva de etnicidade, pensada por Fredrick Barth e reforçada por Philippe Poutignat e Jocelyne Streiff-Fenart, como uma forma de organização social, baseada numa atribuição que classifica as pessoas por uma origem suposta e é validada na interação social. Na opinião destes autores, as definições endógenas e exógenas das identidades étnicas transformam a etnicidade num processo dinâmico sempre sujeito à redefinição e à recomposição. POUTIGNAT, Philippe \& STREIFF-FENART, Jocelyne. Teorias da etnicidade seguido de Grupos étnicos e suas fronteiras de Fredrik Barth. São Paulo: Editora da Unesp, 1998, p. 141.

9 MONTEIRO, John Manuel, op. cit., 2001, p. 56. Vários autores ao longo dos últimos anos utilizaram o conceito de etnogênese. Um exemplo é o estudo de WHITEHEAD, Neil. Etnogeneses and ethnocide in the European occupation of native Surinam, 1499 - 1681. In: D. HILL, Jonanthan. History, power and identity. Lancelot, Iowa City: University of Iowa Press, 1996, p. 20-35. Neste trabalho, ele analisa as populações nativas das Guianas entre os séculos XV e XVII, discutindo a sua "formação étnica". A esse "processo histórico de formações étnicas", que envolveu europeus, africanos e ameríndios na região por ele estudada, deu o nome de etnogênese. Outro autor que também defende o conceito de etnogênese é SIDER, Gerald. Indentity as history, ethnohistory, ethnogenesis and ethnocide in the Southeastern United States. Identities, 1, n. 1, 1994. Ele defende a ideia de que as populações que tomou por foco de análise reconstituíram suas identidades nativas em função das mudanças provocadas pelo contexto em que estavam inseridas.
} 
REVISTA DE HISTÓRIA

SÃO PAULO, N ${ }^{\circ} 168$, p. 69-99,

JANEIRO / JUNHO 2013

Mais recentemente, Guillaume Boccara, tratando sobre os processos de mudança identitária dos Mapuche ocorridos no período de dominação colonial espanhola, na região conhecida hoje como Chile, usou o conceito de etnogênese e fez uma crítica à mestiçagem lida somente como um processo unidirecional de diluição da identidade cultural indígena em razão da construção do ideal das novas nações latino-americanas a partir do século XIX. Boccara critica a visão essencialista das culturas indígenas segundo a qual as modificações da tradição e da reconfiguração étnicas resultariam numa perda da pureza original. Em consequência, essas visões historiográficas tornaram o protagonismo indígena invisível e silenciaram suas ações à medida que os consideravam como sujeitos pré-políticos. Sua proposta seria então a de descolonizar a noção de mestiçagem, buscando, neste processo, formas criativas de ações indígenas. ${ }^{10}$

Para além do pressuposto da dinâmica das identidades, este trabalho também é sensível à percepção simbólica das relações sociais. Considerando que os padrões culturais norteiam a construção das representações do real, essas fontes foram analisadas como construções discursivas - possuindo um sentido retórico e compartilhando um campo semântico definido. Portanto, os relatos dos dois jesuítas aqui analisados foram considerados como discursos que constituíram narrativas com fins específicos. Ao mesmo tempo, também foram lidos como veículos de informações privilegiadas.

Possuindo um sentido edificante, esses relatos jesuíticos obedeciam a certas regras, dentre as quais as que diziam respeito ao registro de sua experiência. Os registros circulavam em todos os quadrantes do mundo onde a ordem jesuítica mantinha missões. ${ }^{11}$ Por conseguinte, o seu modo de proceder

\footnotetext{
${ }^{10}$ BOCCARA, Guillaume. Poder colonial e etnicidade no Chile: territorialização e reestruturação entre os Mapuche da época colonial. Revista Tempo, n. 23. Rio de Janeiro: Editora da UFF, 2007, p. 56-72. Ampliando os diversos sentidos da mestiçagem, que englobam desde mestiçagem forçada, hibridação interindígena e mestiçagem interétnica, Boccara estabelece um vínculo entre estas mestiçagens e o que denominou de etnificação e etnogênese. Neste sentido, os processos de etnificação seriam oriundos das tecnologias do saber/poder implementadas pelo poder colonial que gerariam técnicas disciplinares que produziriam um efeito sobre as estruturas objetivas e cognitivas de determinado grupo. Em contraponto, os processos de etnogênese seriam oriundos da ação criativa endógena de determinado grupo étnico.

${ }^{11}$ A missão é aqui pensada como uma atividade que tinha por objetivo o processo de conversão ao cristianismo dos gentios através da divulgação do evangelho por parte dos missionários católicos. No contexto temporal e espacial aqui proposto, o processo de catequese era realizado nas aldeias missionárias criadas especialmente para este fim. Para o estudo mais amplo do sentido da missão como um espaço de construção e reconstrução de códigos em que padrões cosmológicos diversos estabeleciam comunicação, existe uma importante e estimulante análise
} 
era sempre retroalimentado pelo conjunto de experiências acumuladas e difundidas a todo o corpo de sua ordem no mundo. O objetivo era o de aprimorar o processo de catequese e conversão. Portanto, as dificuldades de seu trabalho missionário eram sempre registradas. ${ }^{12}$ Ainda que tenham sido filtradas informações consideradas pouco relevantes ou mesmo contrárias a sua função edificante, as narrativas deixavam sempre escapar, nos interstícios do discurso, nas dissonâncias da ordem, processos de apropriação. ${ }^{13}$

Apropriações de diversas ordens - fossem no âmbito dos comportamentos sexuais, dos padrões culturais, da religiosiosidade, das táticas de guerra e dos processos de aliança - criavam uma opacidade no campo semântico instituído pela nova ordem. Antes de terem sucumbido física e simbolicamente, mesmo violentamente deslocados de seus complexos universos cosmológicos, esses personagens conseguiram criar espaços alternativos em que o campo da luta era mais refinado e encoberto. A identidade de índios cristãos por eles apropriada significou a resposta inovadora que deram ao

da antropóloga Paula Monteiro que busca apresentar o que chamou de "teoria da mediação cultural". As missões são compreendidas como espaços de mediação em que os agentes (missionários e indígenas) criaram processos de produção de novos significados. Ela demonstra, a partir de uma crítica ao conceito de aculturação, como, nas zonas de intermediação cultural, a incorporação de valores pelos indígenas não significou uma perda cultural pela imposição de valores ocidentais, mas a eficácia da significação se deu como resultado de disputas simbólicas mediadas pelos agentes nela envolvidos, ressaltando a dimensão política dos processos de significação. MONTEIRO, Paula. Índios e missionários no Brasil: para uma teoria da mediação cultural. In: Idem (org.). Deus na aldeia. Missionários, índios e mediação cultural. São Paulo: Globo, 2006, p. 31-66.

12 Através da epístola jesuítica, foi possível, aos membros da Companhia, justificar as normas que produziam localmente. Desta forma, as correspondências, ligadas ao "modo de proceder" emanado das "confissões" da ordem, eram instrumentos capazes de justificar as práticas missionárias concedendo à experiência uma importância substancial na formulação dessas mesmas regras. Sobre a lógica deste sistema de comunicação, ver: EISENBERG, José. As missões jesuíticas e o pensamento político moderno - encontros culturais, aventuras teóricas. Belo Horizonte: Editora da UFMG, 2000. Sobre o significado dos relatos edificantes e das crônicas produzidas pelos missionários ver: TORRES-LONDOÑO, Fernando. La experiencia religiosa jesuítica y la crónica misionera de Para y Maranhão en el siglo XVII. In: NEGRO Sandra; MARZAL, Manuel (org.). Un reino en la frontera: las misiones jesuíticas en la América colonial. Quito: Abya-Yala, 1999.

${ }^{13}$ A ação criativa desses índios ao usarem objetos e códigos do colonizador, uma verdadeira "invenção do cotidiano", subvertendo, em determinadas situações, a ordem dominante, se inspirou na ideia fecunda desenvolvida na obra: CERTEAU, Michel de. A invenção do cotidiano - artes de fazer. Petrópolis: Vozes, 1994. Utilizando-se da antropologia, sociologia e linguística, este historiador estudou os modelos de ação característicos dos "usuários" enquanto consumidores de uma "cultura", sob o estatuto de dominados. Pretendeu, através das maneiras de fazer, perceber atos criativos que subverteram a ordem estabelecida. 
projeto colonizador. Era uma forma de se apropriarem de seu destino. Ser cristão era uma decisão, ainda que por vezes forçada. ${ }^{14}$

No interior das suas práticas cotidianas, é possível encontrar uma série de ações que visavam à manutenção de seus espaços de "liberdade". 15 Diversos líderes indígenas em todo o território hoje conhecido como Brasil já foram apresentados, seja por uma historiografia mais tradicional que os identificava como aliados e colaboradores, seja por uma historiografia renovada que os aponta como protagonistas de sua história. ${ }^{16}$ Este artigo busca revelar personagens ainda mais obscuros - marginais entre os marginalizados. ${ }^{17}$ Mesmo submersos nas narrativas, ainda figuram difusos nos discursos. Eles eram pilotos, remeiros de embarcações, guerreiros, artesãos, oficiais diversos, mulheres e crianças.

${ }^{14}$ CARVALHO JÚNIOR, Almir Diniz de. Índios cristãos - a conversão dos gentios na Amazônia portuguesa, (1653-1769). Tese de doutorado, Unicamp, Campinas, 2005.

${ }^{15}$ É necessário vincular a palavra liberdade ao campo semântico a qual pertence. Tanto do ponto de vista das diretrizes políticas e filosóficas da Coroa portuguesa quanto da perspectiva das cosmologias ameríndias, a ideia de liberdade é completamente estranha ao que hoje podemos entender como tal. Para uma análise sobre o significado do trabalho e da liberdade no contexto do Diretório dos Índios, no Grão-Pará do século XVIII, ver o interessante texto de COELHO, Mauro Cezar. A cultura do trabalho - O Diretório dos Índios e um novo paradigma de colonização na Amazônia do século XVIII. In: QUEIROZ, Jonas Marçal de e COELHO, Mauro Cezar (org.). Amazônia - modernização e conflito. Belém: UFPA/Naea; Macapá: Unifap, 2001, p. 55-79.

${ }^{16}$ Entre os diversos que trataram sobre o protagonismo indígena, destacam-se: Elisa Frühauf Garcia revela como os índios das missões do sul do Brasil, em contato e negociação com os portugueses, influenciaram, através de sua agência política, a produção das políticas indigenistas do Império lusitano. GARCIA, Elisa Frühauf. As diversas formas de ser índio - políticas indígenas e políticas indigenistas no extremo sul da América portuguesa. Rio de Janeiro: Arquivo Nacional, 2009; para o Rio de Janeiro, o importante trabalho da historiadora ALMEIDA, Maria Celestino de. Metamorfoses indígenas - identidade e cultura nas aldeias do Rio de Janeiro. Rio de Janeiro: Arquivo Nacional, 2003. Ela desvenda os caminhos até então ocultos da participação efetiva das populações ameríndias na construção do Rio de Janeiro colonial, explorando o processo de transformação de parte destas populações em súditos da Coroa, inclusive com a sua inclusão no quadro da nobreza colonial. Sobre como os índios ditos coloniais criaram espaços de autonomia nas Minas Gerais, ver: RESENDE, Maria Leônia Chaves de. Gentios brasílicos - índios coloniais em Minas Gerais setecentista. Tese de doutorado, Unicamp, Campinas, 2003. Outros trabalhos, entre dissertações e teses de mestrado e doutorado, surgiram nos últimos anos sob a batuta de John Manuel Monteiro que, a partir da publicação de seu hoje clássico: MONTEIRO, John, op. cit., 1994, orientou diversos trabalhos que, definitivamente, incorporaram as populações ameríndias como protagonistas na história do Brasil. Para acessar essas novas contribuições, ver: www.ifch.unicamp.br/ihb/, acessado em 24/02/2013.

${ }^{17}$ Sobre a ação dos líderes indígenas entre os séculos XVII e XVIII no então Estado do Grão-Pará, hoje parte da Amazônia brasileira ver: CARVALHO JÚNIOR, Almir Diniz de. Líderes indígenas no mundo cristão colonial. Canoa do Tempo - Revista do PPGH/UFAM, v. 1, n. 1. Manaus: Edua/ Fapeam, 2007, p. 123-150. 


\section{Pilotos, remeiros, artesãos e outros oficiais}

Em termos de mobilidade e possibilidade de integração à nova ordem colonial, os índios menos "ilustrados" tiveram bastante vantagem sobre seus líderes. A exceção acontecia nos momentos de guerras, como se verá adiante. O domínio de determinada atividade ou ofício permitia a esses índios "comuns" um destaque e alguma vantagem que, na maioria das vezes, significava evitar os trabalhos pesados, como os destinados a quem não teve a sorte de desenvolver determinado talento.

Das atividades de prestígio, as de pilotos e guias experientes eram as mais comuns. Por sua habilidade de localização nas matas e através de uma técnica que envolvia, entre outras coisas, um olfato mais apurado do que o dos brancos e o uso de sinalização imperceptível a quem não compartilhasse de sua capacidade de enxergar nos matos, eram os senhores das florestas. Eles entravam e saiam delas sem grandes dificuldades, ainda que fossem meninos. Isso era impossível para os brancos que, por pouco que adentrassem nas matas, acabavam por se perder para sempre. Os índios, nos rios e mares, eram também incomparáveis e conheciam todas as ilhas e furos. Chamados de práticos, eles eram imprescindíveis para as viagens fluviais. Os navios não se aventuravam naquelas águas sem levar consigo algum daqueles tapuias como prático. ${ }^{18} \mathrm{O}$ conhecimento dos rios e das técnicas de navegação era questão de honra para os índios e chegavam a arriscar a própria vida para não perderem as embarcações. Era para eles honra e glória saber livrá-las dos perigos e, por oposto, grande desonra caso fracassassem. Muitos eram chamados de "jacumaíbas" - nome originário das pás que alguns deles usavam no lugar do leme, chamadas jacumá. ${ }^{19}$

\footnotetext{
${ }^{18}$ Naquele período, Tapuia era o índio genérico. A nomeação de Tapuia nasceu no início do período colonial na América portuguesa e identificava aquelas populações indígenas que não falavam a língua Tupi. Portanto, antes esta nomeação foi associada aos índios mais arredios, mais bárbaros e selvagens do que os de origem Tupi. Para um estudo que demonstra como o discurso ocidental, sob a ótica da filosofia natural portuguesa, classificou e transformou Tapuia em identidade genérica indígena, ver: CARVALHO JÚNIOR, Almir Diniz de. Tapuia - A invenção do índio da Amazônia nos relatos da viagem filosófica (1783-1793). In: CARVALHO JÚNIOR, Almir Diniz de e NORONHA, Nelson Matos de (orgs.). A Amazônia dos viajantes - História e ciência. Manaus: Edua/Ufam, 2011, p. 33-103. Sobre a transformação de identidades dos ameríndios na história do Brasil e sobre uma análise crítica das representações historiográficas sobre estas populações, ver: MONTEIRO, John. op. cit., 2001.

${ }^{19}$ DANIEL, João, op. cit., tomo I, 1976, p. 253.
} 
Bettendorff, quase um século antes, já registrava a importância desses pilotos para qualquer jornada que se fosse empreender e os lugares onde buscar estes especialistas. Buscou um deles, em 1674, na aldeia Maracanã, embora ele tenha fugido durante a noite. Muitos deles, como o que fugiu, não aceitavam qualquer trabalho, salvo se fossem forçados. ${ }^{20} \mathrm{~A}$ missão de Maracanã era uma das povoações coloniais mais importantes estabelecidas naquelas terras. Uma de suas funções era fornecer pilotos para a navegação da costa entre o Pará e o Maranhão. Seus pilotos eram considerados os melhores para enfrentar aqueles mares e perigosas baias e para isso eram treinados desde muito pequenos na técnica dos remos. Ainda crianças, os pais lhes faziam os remos do tamanho necessário a cada idade. O treinamento era intenso, com descanso apenas de duas a três horas por dia para comerem e dormirem. Já adultos, remavam de modo tão uniforme que produziam uma verdadeira coreografia:

Cada vez que tiram os remos da água, e levantam os corpos, dão com eles uma pancadinha no bordo, cujo som uniforme e conforme arremeda o das danças dos paus, ou cajados, cujas pancadas variam ao mesmo passo, e compasso, que variam o modo de remar; porque também no remar usam de vários modos, já pausados, e já apressados: umas vezes dão 3 remadas aceleradas, e de terno em terno uma pancadinha; outras vezes, além das pancadas, levantam os remos, e com eles floreiam no ar: semelhantes a estes têm muitos outros brincos, com que vão enganando o trabalho e divertindo os passageiros. ${ }^{21}$

O compasso dessa dança era dado pelo proeiros; abaixo dos jacumaíbas, eles tinham o primeiro lugar nas canoas. A hierarquia era respeitada de tal forma que caso morresse algum dos dois pilotos que viajavam na canoa, quem o sucedia era um dos proeiros, conforme o seu tempo de serviço. É muito provável que todo o ritual da dança dos remos tenha sido uma invenção colonial: uma adaptação da técnica tradicional para as exigências coloniais, que os obrigavam a desenvolver uma agilidade e velocidade constantes, aliadas a um número de horas de trabalho nos remos absurdamente extenuantes. Portanto, o que João Daniel destaca como sendo educação e treinamento dos meninos fazia parte, provavelmente, de uma estratégia vi-

\footnotetext{
${ }^{20}$ BETTENDORFF, João Felipe. Crônica dos padres da Companhia de Jesus no Estado do Maranhão. Belém: Secult, 1990, [1910], p. 301. Sobre o principal Lopo de Souza e um inusitado conflito com o padre Antônio Vieira, ver: CARVALHO JÚNIOR, Almir Diniz de. O poder das cruzes. In: Idem, op. cit., 2005, p. 85-119. As expedições militares ou comerciais comumente recebiam o nome de "resgates".

${ }^{21}$ DANIEL, João, op. cit., tomo I, 1976, p. 253-254.
} 
sando adaptar seus corpos às exigências do trabalho ou mesmo uma forma de livrar os filhos de destino pior.

Uma viagem de canoas ao sertão era um empreendimento complexo. Durava em torno de seis a oito meses. Para empreender esta jornada era imprescindível uma portaria do governo. Ademais, entre os mantimentos para a jornada estavam panos diversos como bretanhas e algodão grosso para o pagamento dos índios. Também eram necessários: chapéus, carapuças, ferramentas, farinhas, aguardentes e miudezas diversas. O maior trabalho, no entanto, era reunir os índios necessários à jornada. Não os conseguiam em uma só missão, senão em muitas. Em cada uma delas, somavam um ou dois remeiros. Da canoa maior partiam outras menores e mais ligeiras a percorrer as missões do entorno em busca dos tais remeiros. Nesses lugares, também compravam alguns mantimentos e farinhas dos próprios índios das povoações.

Chegados à missão, apresentavam a portaria ao seu missionário e este chamava o principal ou outro oficial público que reunia os índios mais capazes. Normalmente, o cabo da canoa $^{22}$ não aceitava os que tivessem menos de 20 anos. Muitas vezes, era difícil juntar os índios necessários na aldeia e seus principais iam buscá-los nos arredores. Depois de reunir a farinha necessária para a viagem, faziam o pagamento dos índios, normalmente duas varas de panos de algodão para cada mês de serviço. Eram também pagos com duas ou até três varas de bretanha para camisa, uns calções ou alguma droga. Recebiam um barrete, um prato de sal com seis agulhas em cima. Ao piloto, por sua vez, davam mais três varas de pano grosso e um corte de tecido mais fino para a saia de sua mulher. ${ }^{23}$

Do pagamento recebido, os índios remeiros cortavam algumas varas de panos para si, o chapéu ou barrete e as demais coisas entregavam às suas mulheres e a seus familiares. Levavam consigo o remo, arco, flechas, uma rede, um balaio com alguma camisa e calções. Levavam ainda um novelo de linhas, agulha e uma cabaça de "jaquitaia", ou malagueta moída. ${ }^{24}$

A alimentação, excetuando o sal e a farinha, obtinham da natureza. Nas paradas que faziam nas ilhas e margens para descansar ou fugir das chuvas fortes - conhecidas como esperas -, os remeiros se embrenhavam nas matas

\footnotetext{
${ }^{22} \mathrm{O}$ cabo da canoa era uma função exercida, normalmente, por um homem branco ou mameluco vinculado a algum colono ou missionário que financiava a jornada. Ele era o líder da expedição e sua tarefa era a de conduzi-la com disciplina para que alcançasse o seu objetivo. Neste sentido, o cargo tinha inspiração militar.

${ }^{23}$ João Daniel, op. cit., tomo II, 1976, p. 56-57.

${ }^{24}$ DANIEL, João, op. cit., tomo II, 1976, p. 57.
} 
REVISTA DE HISTÓRIA

SÃO PAULO, N ${ }^{\circ} 168$, p. 69-99,

JANEIRO / JUNHO 2013

com seus arcos e flechas em busca dos alimentos. No lugar da espera, ficava somente o cabo da canoa juntamente com um piloto que exercia o papel de cozinheiro e ajudante. Normalmente, era realizada uma "espera" a cada 24 horas - era o tempo destinado ao descanso e à alimentação daqueles índios. Outras vezes, indo os cabos com pressa, eram raras as esperas e, caso não levassem algum alimento, os homens dos remos passavam fome, comendo somente farinha com água que chamavam de tiquara. ${ }^{25}$

As viagens eram longas e cansativas para os remeiros. A exceção acontecia quando encontravam bons ventos em que se levantavam as velas das canoas. Livres dos remos, podiam acompanhar os brancos e passageiros comendo, cachimbando e dormindo. Depois, aportavam nas primeiras praias em busca das feitorias de manteiga de tartarugas. Ali, brancos e índios se fartavam dos ovos cozidos. Comiam também as pequenas tartarugas que saíam dos ovos para ganhar a praia. Essas feitorias garantiam o alimento para seguirem viagem.

Em busca das drogas mais nobres, saíam os remeiros em outras praias à cata do cacau, da salsa e do cravo - de acordo com os objetivos do cabo da expedição. Também buscavam: copaíba, baunilhas e grandes pescarias de peixe boi, cuja carne salgavam para a alimentação na longa viagem. Na espera pelos produtos, semeavam milho, legumes e outros produtos pelas praias que nas vazantes ficavam descobertas, já que as esperas poderiam durar meses. Caso os índios não demonstrassem diligência em seu trabalho de recolher as drogas, no seu retorno eram, por vezes, surrados. ${ }^{26}$

Os conflitos entre cabos, em geral brancos, e índios pilotos ou remeiros não eram incomuns. Para João Daniel a morte de brancos por "índios mansos" acontecia pelos primeiros tratarem os últimos com desumanidade. Cita o caso de um cabo que, levando uma mulher em sua companhia e por suspeitar que o piloto olhara algumas vezes para ela, mandou-o prender, amarrar e açoitá-lo por um negro escravo que levava. Os açoites se repetiram e o cabo forçou o índio a "beber as águas da mesma manceba". Quando o índio se viu livre do castigo:

(...) vendo ao branco descuidado mudando roupa no camarote, lhe despediu, e cravou uma taquara de banda e banda, sem lhe deixar mais alentos, do que chamar o miserável branco já ansiado com a morte com um grito, pelo negro escravo seu [valentão],

${ }^{25}$ DANIEL, João, op. cit., tomo II, 1976, p. 58.

${ }^{26}$ DANIEL, João, op. cit., tomo II, 1976, p. 60. 
que lhe acudisse; o que na verdade queria fazer saindo à carreira lá da tolda da canoa, onde ia; mas o índio com outra taquara lhe quebrou os brios, porque atravessado caiu mortal; servindo ao branco de mortalha a mesma camisa, que estava vestindo; mas foi digna pena da sua crueldade. ${ }^{27}$

Eram muitas as estratégias para se livrarem dos pesados serviços. Alguns grupos de índios eram especiais nadadores. Os "Mamainases", depois de se aldearem, desenvolveram técnicas de nado que lhes valiam a liberdade quando assim o desejavam. ${ }^{28}$ Nas viagens que empreendiam a mando dos portugueses, fugiam das canoas de modo galante. Neste trecho, João Daniel expõe a refinada técnica:

Como no seu modo de remar dobram os corpos (...) dobram de modo, que mergulham, indo de cabeça abaixo, o remo nas mãos, e vão surgir abaixo a uma boa distância; e depois ou se encostam a terra, onde fazem uma ligeira jangada, ou servindo-se do remo por barco, navegam para a sua aldeia. Também quando lhes parece desertam da aldeia, e se vão meter, e esconder nos matos, principalmente quando se temem de alguma tropa, ou serviço maior (...). E de tal sorte se escondem por aquelas ilhas, que nem que se busquem com cães de caça, se acham até lá se resolverem a voltar para sua missão; e alguns há, que por lá vivem anos, e anos, e outros morrem sem que os seus missionários o saibam. ${ }^{29}$

Outros índios habitantes das ilhas do rio Tocantins, chamados pelos portugueses de nação dos canoeiros, eram arredios ao mundo branco e assaltavam as fazendas de gado das margens dos rios utilizando para tanto o auxílio de seus ferozes cães. Daniel afirma que os tais cães não podiam ser domesticados e fugiam dos brancos e europeus, como muitos pecadores da igreja e como o diabo da cruz. Segundo o jesuíta, eram mais ferozes que os tigres e chegavam a dominar um touro com facilidade. Os canoeiros eram também hábeis nadadores e seguiam por baixo da água como se fossem peixes. Eles tinham a habilidade de alagar as canoas para fugirem dos brancos que vinham ajustar contas dos bois que haviam subtraído ou morto com seus cães, quando não conseguiam fugir correnteza abaixo "como pássaros". Alagavam a canoa e a metiam no fundo do rio com destreza e rapidez. Com a mesma facilidade mergulhavam por baixo das águas e surgiam muito

\footnotetext{
${ }^{27}$ DANIEL, João, op. cit., tomo II, 1976, p. 66.

${ }^{28}$ Sobre esta guerra ver: CARVALHO JÚNIOR, Almir Diniz de. O poder e os gentios da terra parte I. In: Idem, op. cit., 2005.

29 DANIEL, João, op. cit., tomo I, 1976, p. 272-273.
} 
REVISTA DE HISTÓRIA

SÃO PAULO, N 168 , p. 69-99,

JANEIRO / JUNHO 2013

distantes onde riam e zombavam dos brancos que, admirados, nada podiam fazer, a não ser, como relata o jesuíta, chupar os dedos. ${ }^{30}$

No retorno da expedição, os cabos iam deixando os índios nas várias missões nas quais os haviam recolhido. Mas havia exceções à regra. Alguns desses índios acabavam por ficar nos sítios dos brancos. Para Daniel, as razões para tal fato eram de dupla origem. Primeiro, porque tais índios não achavam modo para voltar rio acima quando solicitados para acompanhar os cabos até o porto de origem das canoas. Segundo, por estarem já "praticados" pelos brancos. É razoável supor que a segunda razão devia ser a principal e talvez a única. Pilotos e remeiros, principalmente os primeiros, eram peças fundamentais para a economia da região. Tê-los sempre à mão era fundamental para o empreendimento das canoas. Portanto, deveriam receber algum retorno por migrarem para as propriedades dos moradores. Praticar, neste caso, era sinônimo de seduzir. ${ }^{31}$

Os índios retirados dos matos e criados como cristãos passavam a desenvolver técnicas e habilidades apuradas. Mandados às missões e às casas dos brancos, esses índios aprendiam os ofícios com tanta destreza e perfeição que a nenhum mestre europeu ficavam a dever. Bastava, por vezes, verem trabalhar algum oficial para o imitarem com admirável perfeição. Entre eles existiam grandes pintores, escultores, ferreiros e oficiais de todos os ofícios. A capacidade de imitarem obras era enorme. A fama deles era tamanha que quando alguém queria uma obra feita com primor não chamava um branco, mas um índio. Os brancos do mesmo ofício, por sua vez, não se envergonhavam de dividir o trabalho com seus discípulos e oficiais indígenas. ${ }^{32}$

Além de escultores, eram carpinteiros de muita qualidade, ferreiros e também alfaiates. Mas Daniel destaca um senão que os deslustrava: era a grande preguiça que os acompanhava. Em razão disto, nada faziam a não ser quando mandados. Mesmo em suas casas não utilizavam a habilidade que possuíam. ${ }^{33}$

Segundo o jesuíta, devido àquela natural preguiça, tais índios somente mostravam suas raras habilidades nas casas ou a serviço dos brancos dos quais eram escravos ou caseiros. Nas missões, por sua vez, se revelavam apenas aqueles que os missionários tinham o cuidado de mandar ensinar para os serviços das missões - normalmente ferreiros, serralheiros, tecelões,

\footnotetext{
${ }^{30}$ DANIEL, João, op. cit., tomo I, 1976, p. 275.

${ }^{31}$ Idem, tomo I, 1976, p. 167.

32 Ibidem, 1976, p. 251.

33 DANIEL, João, op. cit., tomo I , 1976, p. 251.
} 
sangradores, carpinteiros, entre outros. Eles somente trabalhavam em suas oficinas quando eram mandados. A interpretação de Daniel revela uma nuança contraditória e faz pensar que a preguiça, em realidade, era simplesmente em razão de não encontrarem qualquer sentido naquele trabalho já que obtinham da natureza tudo o que era necessário a sua sobrevivência. ${ }^{34}$

Sendo tais índios tão hábeis, é fácil imaginar que, no contexto colonial, passavam a ter um valor diferenciado seja para moradores, seja para missionários. Assim, Daniel reclama da falta de cuidado quando da repartição dos índios para equiparem as canoas. Reclama de que muitos, obrigados a ir como remeiros pelos militares, tinham algum treinamento. Entre eles: sacristãos, músicos e catequistas treinados pelos missionários para ajudar nos ofícios divinos. Portanto, as repartições eram um estorvo para a conversão e, principalmente, para o aumento das aldeias.

A utilidade dos ofícios nas aldeias era inegável. Bettendorff se refere em seu texto a vários destes índios artesãos. Um deles, inclusive, chamado por ele de índio carapina bizarro, foi quem erigiu sozinho a residência dos jesuítas de Gurupy. Segundo ainda o jesuíta, esse índio era tão "destro" em seu ofício que nenhum branco podia superá-lo em qualidade de trabalho. ${ }^{35}$

Os carapinas ou carpinteiros eram também indispensáveis para se erigir qualquer edifício na região. Com florestas abundantes e ricas em madeiras, era fundamental tê-los sempre à mão num momento de necessidade. É provável que tais índios tenham adaptado sua técnica milenar à exigência dos modelos europeus. Eram requisitados tanto nas missões quanto nas propriedades dos moradores brancos por óbvia razão.

\section{Guerreiros}

A guerra fazia parte da cultura ameríndia. Em algumas etnias, como entre os Tupinambá, a atividade era fundamental e mesmo, segundo alguns autores, era-lhes constitutiva. ${ }^{36}$ No mundo colonial, certamente houve a mutação

\footnotetext{
${ }^{34}$ Idem, tomo I, 1976, p. 253.

${ }^{35}$ BETTENDORFF, João Felipe. Crônica dos padres da Companhia de Jesus no Estado do Maranhão. Belém: Secult, 1990 [1910] , p. 255.

36 Sobre a função da guerra na sociedade tupinambá, ver: FERNANDES, Florestan. A função da guerra na sociedade Tupinambá. São Paulo: Editora da USP/Livraria Pioneira Editora, 1970 [1952]. Mais recentemente, ver também: VIVEIROS DE CASTRO, Eduardo e CARNEIRO DA CUNHA, Manuela. A vingança e temporalidade: os Tupinambá. Journal de la Societé des Americanistes, n. 71, 1985, p. 191-217.
} 
desse padrão referencial tradicional, mas a figura do guerreiro manteve-se. A própria estratégia de cooptação de líderes indígenas alimentava-se do seu furor guerreiro. Os ofícios de principal, capitão e sargento-mor foram instituídos para tais índios tendo por base a necessidade das alianças militares.

As técnicas militares tradicionais desses índios eram muitas vezes mais eficientes que aquelas originadas no velho mundo. Sem o apoio decisivo dos arqueiros indígenas, as tropas portuguesas não teriam conseguido implantar e conservar a sua hegemonia em território "amazônico". Seu conhecimento dos terrenos, o uso dos mais diversos tipos de venenos e a estratégia de ataques de guerrilha atordoavam seus inimigos. Nas florestas, os estrategistas europeus tinham que se curvar diante do guerreiro indígena.

Em face das guerras constantes que aconteciam no mundo indígena, diversos grupos estabeleciam entre si alianças com o intuito de se defenderem ou atacarem de forma mais eficiente seus inimigos. Portanto, não houve dificuldade em delas se utilizarem quando da chegada em seu território dos brancos europeus. As alianças se fizeram entre eles e os estrangeiros ou entre outros grupos indígenas objetivando fins diversos. ${ }^{37}$

As armas mais comuns utilizadas eram o arco e as flechas e nas campanhas de guerra as utilizavam maiores. Pelo tamanho e impulsão de seus arcos, eram mortais instrumentos que não somente transpassavam um homem, mas também uma peça de madeira de qualquer qualidade e espessura. Eram taquaras de sete a oito palmos de comprimento e da grossura de um pulso de menino. Chegavam a atingir seu alvo a 150 metros ou mais de distância. Usavam também zarabatanas com setas envenenadas que bastavam tocar a pele do inimigo para matá-lo em pouco tempo, mas eram de eficiência menor, já que, devido às roupas dos europeus que incluíam chapéus e couraças, poucas conseguiam tocar os corpos. Maior eficiência eles obtinham com seus arcos, devido à maestria com que os manejavam - deles saíam tão ligeiros os projéteis que, enquanto um soldado carregava sua espingarda, atiravam mais de dez, doze ou mais flechas. ${ }^{38}$

"Os assaltos repentinos" eram a mais eficiente das técnicas militares desses guerreiros indígenas. Os europeus não estavam acostumados a esse tipo de estratégia e consideravam-na odiosa, mas de terrível eficiência. O

\footnotetext{
${ }^{37}$ Para um panorama das guerras indígenas e coloniais, ver: ALMEIDA, Maria Regina Celestino de. Guerras indígenas e guerras coloniais/pós-coloniais. In: Idem. Os índios na história do Brasil. Rio de Janeiro: Editora FGV, 2010, p. 45-69.

${ }^{38}$ DANIEL, João, op. cit., tomo I, 1976, p. 234.
} 
descuido de seus inimigos era sua vantagem maior. Escondidos entre os arvoredos às margens dos rios, atacavam as canoas que tentavam revidar sem sucesso, uma vez que se mantinham camuflados à sombra das árvores e protegidos por seus troncos. Atacavam também seus inimigos tradicionais quando estavam em suas festas ou distraídos pelos rios. Ao capturarem mulheres e crianças, os escravizavam ou desferiam contra eles sua vingança.

Outra técnica utilizada era manterem sempre espias no alto das árvores para vigiarem os rios. Quando avistavam o inimigo, tocavam um grande tambor feito do tronco de árvore que escavavam por dentro com ajuda do fogo. Mantinham-no suspenso do solo entre forquilhas. O som deste instrumento podia alcançar, segundo Daniel, de três ou mais léguas, mas somente eram tocados nas ocasiões das guerras. Quem ouvia o som se recolhia ao "arraial", armando-se com seus arcos e flechas. Quando os inimigos os encontravam prevenidos desta forma, normalmente se retiravam sem atacá-los.

O jesuíta afirma que, caso tivessem quem os liderasse, nem toda a Europa seria suficiente para desalojá-los de suas terras. Bastava que usassem suas técnicas, entre as quais o ataque pelas margens dos rios, escondidos entre os arvoredos. Dessa forma, artilharia nenhuma conseguiria atingi-los. Ainda que os invasores tentassem encurralá-los com fogo, não conseguiriam. As florestas daquela região não permitiam incêndios de grandes proporções, ficando o fogo restrito à lenha seca.

Boa parte dessas técnicas militares ficou a serviço dos brancos. Seus aliados guerreiros, lustrados com honrarias, passaram a compor as tropas nos combates aos inimigos europeus da Coroa e, por esse motivo, usufruíram um status diferenciado. ${ }^{39}$ Terminados os conflitos, passaram a cuidar do controle dos índios arredios que não aceitavam o domínio do invasor. Com o tempo, as honrarias foram diminuindo, assim como o prestígio que ganharam nos primeiros anos de conquista.

Um exemplo singular demonstra a perda de prestígio destes aliados guerreiros. Bettendorff narra que a missão na serra do Ibiapaba extinguiuse devido aos conflitos entre uma tropa enviada pelo governador Rui Vaz de Siqueira e um antigo aliado índio principal de nome d. Simão. A tropa era composta por mulatos, mamelucos e muitos índios das aldeias do Maranhão

\footnotetext{
39 Sobre as honrarias que foram dadas a diversas lideranças indígenas ver: CARVALHO JÚNIOR, Almir Diniz de. Líderes indígenas no mundo cristão colonial. Canoa do Tempo - Revista do PPGH/ UFAM, v. 1, n. 1, Manaus: Edua/Fapeam, 2007, p. 123-150. Sobre a construção de nobreza indígena no Rio de Janeiro do século XVI, ver: ALMEIDA, Maria Regina Celestino de, op. cit., 2003.
} 
e foi resgatar âmbar na região daquelas "nações" com a desculpa de ver se os missionários necessitavam algum socorro. Inicialmente, foram bem hospedados pelos missionários e demais índios cristãos. Três meses após, estes índios passaram a evitá-los, afastando-se da tropa pelo incômodo que causavam. D. Simão, seu líder, solicitou que se retirassem daquelas aldeias. Este principal era portador de uma grande medalha de ouro em que, de um lado, encontrava-se o hábito de Cristo e do outro a imagem do rei. Este medalhão teria sido dado a ele pelo padre superior da missão, Antônio Vieira.

O cabo da tropa zombou do pedido do principal e ameaçou matá-lo armando uma forca no meio do terreiro. D. Simão era guerreiro experiente e lutara nas guerras de Pernambuco ao lado dos portugueses. Portanto, recuou estrategicamente e buscou apoio entre os "tapuias" das aldeias vizinhas, objetivando aliar-se a eles contra aquelas tropas do Maranhão.

D. Simão conseguiu o seu apoio e juntos prepararam emboscadas durante a noite e mataram alguns índios da companhia dos soldados que andavam despreocupados. Amanhecendo, invadiram a aldeia aos gritos. Para completar, colocaram fogo em muitas casas. ${ }^{40}$

Retiraram-se os índios de d. Simão somente para no outro dia atacarem com mais força a mesma aldeia - queriam minar as forças do adversário e vencer a guerra. Enquanto uma parte dos guerreiros atacava a aldeia, outro grupo isolava os adversários que se mantinham fortificados. Com machados, derrubaram árvores grossas para impedir o caminho de acesso à água. Por trás das mesmas, emboscaram seus inimigos matando eflechando os que iam para o rio.

Acabaram por vencer seus rivais. A tropa se retirou, assim como os padres missionários que, assustados, não queriam mais confiar no antigo aliado cristão pelo fato de terem-no antes colocado a ferros já que era um amancebado sem emendas, com grande escândalo e ruína dos demais. ${ }^{41}$

No tempo do mesmo governador Rui Vaz de Siqueira, outra tropa foi mandada por ele, em direção oposta, atrás de resgatar escravos. Partiu para o rio Amazonas tendo por cabo o sargento-mor Antônio Arnaud. O sargento teria sido um dos líderes da primeira expulsão dos jesuítas das terras do Maranhão, no ano de 1661, quando foi também expulso Antônio Vieira. O relato edificante de Bettendorff, ao narrar os infortúnios do dito cabo da tropa, tem um objetivo moral - o fim que levou teria sido justo castigo para expiar suas

\footnotetext{
${ }^{40}$ BETTENDORFF, João Felipe, 1990, p. 199.

${ }^{41}$ Idem, p. 200.
} 
culpas. O mais interessante do relato é que menciona como o tal militar experimentado foi ludibriado pelos próprios índios que tentava explorar.

O cabo da tropa resolveu entrar pelo Amazonas, o que não constava das ordens que trazia. Ele entrou pelo rio dos Aruaquizes, onde os jesuítas tinham missões. Recebido por esses índios aliados, passou a exigir que capturassem e lhe entregassem um número cada vez maior de escravos. Não contente com a quantidade trazida, Arnaud passou então a saquear algumas aldeias vizinhas. Existia na região cerca de noventa e seis aldeias dessa etnia às quais o cabo da tropa ambicionava tornar cativas. Os índios, então, convenceram-no a dividir suas forças entre várias aldeias na promessa de que assim conseguiria mais escravos. A artimanha era para matá-los com mais segurança e menos resistência. Usaram também uma ardilosa estratégia para matar Arnaud. Dividiram-se em várias emboscadas. Numa delas, entraram na fortificação em que se encontrava o cabo da tropa com muitas índias amarradas como se fossem escravas. Os soldados prontamente deixaram-nos entrar. Dissimuladamente, chegaram à choupana em que se encontrava o sargento-mor. Bettendorff conta o fim da história:

Alegre o Arnaud com estas vozes e vindo a receber seguramente as presas que se lhe
ofereciam, sem levar armas nenhuma consigo (...) ao sair da porta, o principal dos Arua-
quizes lhe deu com um pau à maneira de massa, desses com que matam gente, uma
pancada sobre a cabeça que logo lha abriu em duas partes, e outra na boca, quebrando-
lhe os dentes e os queixos (...) morrendo à vista de todos, sem sacramentos, aquele que
foi causa de tantas almas os não gozarem. Esteve três dias penando sem acordo algum,
movendo somente aquela boca que tanto falou contra os religiosos, de vida inculpável. ${ }^{42}$

No relato repleto de apelo moral, Bettendorff menciona o vínculo que se estabelecia entre a Companhia de Jesus e alguns principais, demonstrando o poder das alianças e o jogo das relações. O jesuíta narra o destino violento de todos os detratores da Companhia. Para ele, um testemunho da justiça divina, mais provável, o resultado da força das suas alianças. Um dos homens chamado Francisco de Miranda, que ia por língua e intérprete da tropa, também teve o mesmo destino que o cabo Arnaud. Miranda morreu juntamente com Arnaud, ambos com as cabeças quebradas. ${ }^{43}$

Outra parte da mesma tropa em que ia o juiz do povo de nome Pero Silveira, outro inimigo dos da Companhia, também foi dizimada violenta-

\footnotetext{
42 BETTENDORFF, João Felipe, 1990, p. 206.

43 Idem, p. 208-209.
} 
REVISTA DE HISTÓRIA

SÃO PAULO, N 168 , p. 69-99,

JANEIRO / JUNHO 2013

mente. Os homens da tropa, entre os quais o juiz do povo, foram ludibriados pelos índios que os levaram direto para uma emboscada. Bettendorff assinala, com ironia:

Foram estes pobres e mal afortunados homens caminhando com muita quantidade de índios, a buscar os cativos que se lhes tinham prometido, com grande festa e alegria, considerando-se ir com muitas riquezas e novos engenhos de açúcar que iam fabricando em sua imaginação (..... ${ }^{44}$

Todos foram mortos, mas Pero Silveira foi levado por eles para ser morto pelo costume gentílico. Costumes tradicionais permaneciam mesmo entre os aliados mais próximos dos portugueses. Muitos guerreiros que iam às tropas não deixavam de exercer essa prática, ainda que o objetivo da guerra fosse estranho à tradição. Isto acontecia quando se viam diante de um inimigo antigo ou mesmo quando davam a tais empresas um significado singular e referendado por seus padrões cosmológicos mais fundamentais.

Sob essa ótica, é possível entender o relato da campanha contra os Tremembé acusados de matarem alguns náufragos. Nesse caso, destaca-se o comportamento dos índios aliados do Maranhão que foram na empresa. Os índios chegaram com tanta fúria, em razão desses índios terem matado muitos parentes seus, que começaram a matar a todos sem perdão, não poupando mulheres e crianças. A estas, pegavam pelos pés e davam com suas cabeças nas árvores. Os que testemunharam a matança se referiram a uma moça branca de extremada beleza, o que não sensibilizou os guerreiros. Ela também teve a cabeça quebrada como os demais. ${ }^{45}$

Como se sabe, o ato de quebrar a cabeça dos inimigos no terreiro e de tomar um nome é dos mais conhecidos rituais Tupinambá. Ele deu margem a todo o imaginário do canibalismo que alimentou, durante séculos, a imagem dos índios americanos. O fato de os guerreiros cristãos praticarem parte de tal ritual revela, senão sua ligação direta com aquele grupo indígena, ao menos uma conexão cosmológica. ${ }^{46}$

O vínculo com a tradição não se resumia somente à permanência de certos rituais nos embates da guerra. Mais que isso, a própria existência e

\footnotetext{
${ }^{44}$ BETTENDORFF, João Felipe, op. cit., 1990, p. 209.

${ }^{45}$ Idem, p. 320.

${ }^{46}$ Sobre a hipótese de um patamar cosmológico comum de base Tupi compartilhado pelas diversas etnias que habitavam esta região, ver: CARVALHO JÚNIOR, Almir Diniz de. A raiz Tupinambá. In: Idem, op. cit., 2005, p. 123-150.
} 
apelo a esses conflitos os mantinham ligados ao sentimento guerreiro que, em vários grupos étnicos, senão em todos, era motor das atividades de maior glória e honra. Portanto, conseguir índios para fazer parte de tropas de guerra não era difícil. Embora fugissem das outras tropas destinadas a recolher drogas do sertão, naquelas que tinham por objetivo castigar ou cativar seus inimigos, antes de serem chamados, se ofereciam.

A atividade da guerra para os índios cristãos era a de maior valor, inclusive para os meninos que ansiavam pela honra e glória de tal atividade. Os meninos que ansiavam por um espaço na nova ordem, que não o dos ofícios mecânicos ou de língua e guias, mas de guerreiros e chefes, eram a matéria prima dos novos cristãos. A eles, os missionários dedicavam especial cuidado, pois significavam o fruto mais completo do seu trabalho de conversão. ${ }^{47}$

\section{Meninos e mulheres}

Uma prática comum utilizada pelos missionários jesuítas para doutrinar os gentios era raptarem seus filhos para impor sua vontade ou, através da conversão dos meninos, conseguir convencer os pais a descerem pelos rios para as aldeias missionárias. João Daniel aconselha que se fizessem seminários, pois estes poderiam se tornar uma das formas mais eficazes para a manutenção dos índios novatos nas missões. Como os índios fugiam muito, bastava ter seus filhos como reféns para garantir sua permanência. Segundo o jesuíta, segurando-lhes os filhos, também tinham seguros os pais. ${ }^{48}$

O recurso ao rapto poderia ser perigoso se feito sem as devidas precauções. Daniel cita um caso de um jesuíta que se incumbia de doutrinar os índios Jurunas e por estarem propensos a retornarem a sua antiga casa, "arrependidos por inconstantes", raptou-lhes os filhos com a desculpa de aprenderem alguns ofícios importantes para as povoações, mas objetivando, na realidade, segurar os adultos na missão mantendo os filhos como reféns. O objetivo não foi alcançado e antes de retornarem para suas matas serviram-se das carnes do padre, de um branco que estava em sua companhia e de alguns tapuias mansos que o acompanhavam. ${ }^{49}$

João Daniel defende que, com os seminários, seria possível converter os meninos e usá-los para doutrinar seus parentes. Uma vez civilizados, eles

\footnotetext{
${ }^{47}$ DANIEL, João, tomo I, op. cit., 1976, p. 201.

48 DANIEL, João, op. cit., tomo II, 1976, p. 230.

${ }^{49}$ Idem, op. cit., tomo I, 1976, p. 268.
} 
seriam os melhores oradores daqueles brutos que não se deixavam penetrar. Segundo opinião do jesuíta, vendo-os vestidos e estimados pelos europeus lhes dariam crédito e logo os seguiriam..$^{50}$

Desde os tempos de Bettendorff, era função dos meninos da missão cuidarem da decoração das igrejas, servirem como sacristãos nas missas e ajudarem na doutrinação dos adultos..$^{51}$ Os meninos da doutrina, assim chamados por João Daniel, se incumbiam, dentre outras tarefas, de cantarem hinos nas missas ou fazerem algum pequeno serviço como plantar hortas. Mas sua função mais importante era a de catequistas. ${ }^{52}$

Esses meninos acabavam por se tornar o esteio do processo de conversão. Educados nas missões, eram os intermediários entre seus missionários e outros índios. Tornavam-se línguas, catequistas, sacristãos e, já crescidos, exerciam atividades como pescadores e caçadores para seus mestres. Próximos que estavam ao missionário, conseguiam certa liberdade de ação e regalias frente aos outros índios da aldeia. Eles formavam a base de sustentação política do missionário junto aos seus parentes. Estavam também próximos da igreja e da religião que, se para alguns de seu povo era cheia de exotismos, para eles, possivelmente, já possuía certo sentido. Arrumando os objetos sagrados do altar, guardando e fabricando as hóstias, tiveram um contato mais profundo com o ritual católico. No entanto, assim como os demais, exercitaram sua capacidade de traduzir a nova crença e vinculá-la ao universo referencial que traziam como tradição..$^{53}$

Ao lado dos catequistas que permaneciam na aldeia para aprender a doutrina estavam as mulheres. Com seus maridos ausentes nas longas viagens para recolher drogas do sertão ou nas tropas de resgate e de guerra, eram, juntamente com os meninos, as que mantinham maior contato com o cotidiano do mundo colonial. Importantes para a manutenção dos serviços domésticos, elas exerciam a atividade de produtoras de tecidos de algodão, artesãs e, nas roças de mandioca, plantavam e recolhiam aquele produto agrícola. Eram chamadas de "farinheiras". Seja qual fosse o núcleo colonial - aldeia missionária, pequena vila ou cidade, a "farinha de pau", produto da mandioca, era essencial para a manutenção da vida. Por outro lado, os panos

\footnotetext{
${ }^{50}$ DANIEL, João, op. cit., tomo II, 1976, p. 230.

${ }^{51}$ Idem, tomo II, 1976, p. 211.

52 Ibidem, tomo II, 1976, p. 46.

53 Alguns destes meninos, já adultos, acabaram por articular uma relação exótica entre o mundo místico europeu e o mundo espiritual do seu povo de origem. Ver: CARVALHO JÚNIOR, Almir Diniz de. Índios hereges. In: Idem, op. cit., 2005, p. 321-367.
} 
de algodão eram também peças fundamentais no circuito das trocas na colônia. Além dessas atividades, as mulheres indígenas penetravam no interior do mundo branco e cristão através das atividades domésticas para as quais eram muito requisitadas. Assim como as negras o faziam no estado do Brasil, no Maranhão e Grão-Pará, as mulheres indígenas exerciam a atividade de "leiteiras" dos filhos dos brancos e, não raro, de amantes de boa parte deles.

Queixava-se João Daniel de que o hábito a princípio positivo de enviar às casas das mulheres brancas as meninas para que estas as educassem, no final das contas, não fora a melhor medida. Para o jesuíta, essas senhoras somente atendiam a suas conveniências, servindo-se das meninas como escravas, pouco se importando com sua honestidade e com sua doutrinação. O missionário defendia que, assim como não era conveniente distribuir as índias adultas como "leiteiras e farinheiras" pelas casas dos brancos, também não o era manter as meninas nessas casas. Ele acreditava que a melhor forma seria mantê-las recolhidas em seminários para que aprendessem algum ofício e depois viessem a ensinar as outras índias nas aldeias da Companhia. ${ }^{54}$

João Daniel argumentava que a sua repartição causava o seu descaminho, uma vez que nunca retornavam para as aldeias às quais pertenciam. No momento de serem entregues de volta, os moradores sempre conseguiam um meio de mantê-las em suas casas com a desculpa de que as reporiam posteriormente ou mesmo que haviam morrido. Por vezes, como relata o jesuíta, quando eram obrigados por pressão das autoridades coloniais, repunham algumas delas com filhos já nascidos, frutos do tempo em que viveram entre os brancos. ${ }^{55}$

O missionário faz uma observação muito interessante que demonstra como as índias cristãs se relacionavam com o mundo dos brancos, à revelia do que gostariam seus "guias espirituais". Dizia que, por vezes, elas mesmas não queriam voltar para sua aldeia, pois os moradores as deixavam contentes em poderem viver sem o constrangimento e a vigilância dos seus missionários, conforme a liberdade de suas consciências. Muitas chegavam a mudar os nomes para não mais serem encontradas. ${ }^{56}$ Para Da-

\footnotetext{
${ }^{54}$ DANIEL, João, op. cit., tomo II, 1976, p. 229.

${ }^{55}$ DANIEL, João, op. cit., tomo II, 1976, p. 213. Muitas destas mulheres tornaram-se especialistas em feitiçaria. Para mais informações, ver: CARVALHO JÚNIOR, Almir Diniz de. Índios hereges. In: Idem, op. cit., 2005, p. 321-367; para estudo de casos, ver: CARVALHO JÚNIOR, Almir Diniz de. A magia do novo - índios cristãos nas fronteiras da Amazônia colonial. Revue Nuevo Mundo Mundos Nuevos, Debates. EHESS, 2011. Disponível em: HTTP://nuevomundo.revues.org/g2258. Acesso em 29/09/2012.

${ }^{56}$ DANIEL, João, op. cit., tomo II, 1976, p. 213.
} 
REVISTA DE HISTÓRIA

SÃO PAULO, N ${ }^{\circ} 168$, p. 69-99,

JANEIRO / JUNHO 2013

niel, essas índias teriam sucumbido a seus desejos e à liberdade de suas consciências devido a sua fragilidade moral. Provavelmente, muitas vezes vivendo numa situação talvez mais incômoda nas aldeias, optavam por permanecerem nas casas dos brancos. Alternativa talvez menos dolorosa já que, por mais contraditório que possa parecer, embora escravas, elas adquiririam mais liberdade. Essa não se restringia, como pensa Daniel, à liberdade sexual, mas principalmente à liberdade de não trabalharem nas roças dos jesuítas e, consequentemente, serem obrigadas a cumprir serviços para vários moradores quando repartidas. Pertencendo somente a uma casa, adquiriam vantagens e, provável, uma extensão de vida. Os favores sexuais, nesse sentido, poderiam ser seu passaporte para uma vida melhor. ${ }^{57}$ Não se pode esquecer, no entanto, que os moradores também necessitavam daquelas índias para trabalhar em suas roças, tecerem e fiarem o algodão e nos serviços domésticos variados. Para tanto, era prática comum casarem as mesmas com alguns escravos seus. A vida não era fácil para essas mulheres. Serem usadas sexualmente por seus senhores certamente não era uma boa opção. As que tinham mais sorte serviam a alguma viúva que normalmente se cercava de várias escravas para tocar sua propriedade.

Como leiteiras, farinheiras, domésticas, artesãs e amantes as índias cristãs transformaram-se no vínculo mais forte entre o mundo branco e o indígena. Por consequência, o rompimento que estabeleceram com a tradição que traziam de seus ancestrais talvez tenha sido mais profundo do que o de seus parentes homens. Algumas se apropriavam mais livremente dos códigos ocidentais: foi o caso da índia que solicitou ao seu missionário que a batizasse e que a instruísse na doutrina o quanto antes, logo ao ser descida com outros índios para uma aldeia missionária. A razão de seu pedido era por se sentir repudiada, ao contrário de outras que conviviam bem com os muitos brancos da missão. Estes não a queriam por não ser cristã. No bispado do Maranhão, era pecado gravíssimo manter o coito com mulheres não cristãs, por isso se via envergonhada diante das demais índias. Daniel complementa: "bem merecia a índia, que logo a crismasse com bons açoites". O rompimento com a tradição, neste caso, poderia significar também manter sexo com os brancos; mas, contraditoriamente, o ato sexual livre poderia estar de acordo com a mesma tradição. Afinal, a maneira de conceber o

\footnotetext{
${ }^{57}$ Sobre as práticas sexuais e de bigamia: CARVALHO JÚNIOR, Almir Diniz de. Índios hereges. In: Idem, op. cit., 2005.
} 
sexo segundo os padrões culturais de algumas populações indígenas não acompanhava a moralidade cristã. ${ }^{58}$

Tratando do significado do adultério para os índios, o jesuíta traça a diversidade das formas que o sexo era por eles percebido:

Tão louvável é a sobredita lei de pena de morte pelo adultério em algumas poucas nações dos índios, e a cautela de outras no recolhimento das filhas até casarem, como é estranhável e censurável o costume a abuso de outras nações do mesmo Amazonas (...) que quando casam é bastante fundamento para o marido repudiar a mulher, o achá-la virgem, e intacta: porque, diz o marido, é tal, que ninguém a quis, e assim também eu a não quero. E as mesmas têm como por desdouro seu o não ser buscadas.59

João Daniel considerava a rudeza daqueles índios muito grande. Isso não os deixava perceber a gravidade e malícia daquele vício. Alguns havia, segundo ele, mesmo já nascidos nas missões e todos os dias doutrinados, que ofereciam as filhas e talvez suas mulheres por qualquer coisa, como um frasco de água ardente. ${ }^{60}$

Pondera o mesmo jesuíta que outros índios já batizados tinham visão distinta sobre o matrimônio. Destaca que alguns maridos eram extremamente "zelosos" com suas mulheres, de tal maneira que elas não podiam se ausentar de sua presença mesmo que fosse por pouco tempo, muito menos por qualquer motivo falarem com homens brancos. Este zelo de determinadas nações, ao contrário de outras, parece ter sido também fruto da mudança comportamental que se estabelecia conforme estes índios se inseriam no novo mundo como cristãos. O jesuíta lembra um caso de um marido índio que foi para o mato e, em sua ausência, passando pela rua um vendedor branco que vendia drogas foi chamado por sua mulher. A índia perguntou de cima de um sobrado quais eram as suas drogas, o que queria etc. Subiu então o marido pela escada do quintal e a esfaqueou, matando-a. ${ }^{61}$

O cuidado e domínio que tinham aqueles índios sobre suas mulheres poderiam ser relacionados ao ódio ou medo que mantinham contra os brancos. As proibições que a elas infringiam tornavam-se mais duras quando o objeto das proibições se relacionava ao seu contato com os brancos. Os Nhengaíbas, por exemplo, embora soubessem falar a língua geral, dela não

\footnotetext{
${ }^{58}$ DANIEL, João, op. cit., tomo I, 1976, p. 211.

${ }^{59}$ Idem, op. cit., tomo I, 1976, p. 210.

${ }^{60}$ Ibidem, tomo I, 1976, p. 211.

${ }^{61}$ Ibidem, op. cit., tomo I, 1976, p. 210.
} 
REVISTA DE HISTÓRIA

SÃO PAULO, N 168 , p. 69-99,

JANEIRO / JUNHO 2013

se utilizavam, nem mesmo nas confissões. Proibiam também suas mulheres terminantemente de falar a mesma língua para que, desta forma, não pudessem manter comunicação com os homens brancos. Em nenhum caso poderiam falar esta língua, ainda que fosse para se confessarem.

O controle sobre suas mulheres impedia que a confissão fosse feita em língua geral - para muitos missionários, único modo de entender os pecados de suas ovelhas. João Daniel deixa escapar, mais uma vez, o recurso à violência utilizado nas missões quando, por algum motivo, a ordem fosse quebrada. Em algumas delas, mesmo seus missionários tendo mandado dar palmadas para que essas mulheres confessassem em língua geral, elas se deixavam sangrar e permaneciam mudas. ${ }^{62}$

Pelos exemplos citados, fica fácil perceber que a vida das nativas não era das mais fáceis. Seu lugar social havia desaparecido no mundo de origem e, naquele que começavam a adentrar, as demandas eram muitas e contraditórias. De um lado, os brancos as utilizavam para o trabalho e para o sexo; de outro, era-lhes imposta uma moral estranha. Eram obrigadas a contrair o matrimônio, muitas vezes com índios de etnias que sequer conheciam as línguas; outras vezes, eram obrigadas a se recolher para que vivessem sem os vícios da carne em honra de uma moral religiosa que, provavelmente para elas, era, no mínimo, exótica.

Estas índias acabaram por encontrar, no mundo colonial, um espaço para seu enquadramento. Dividiam com as brancas vindas da corte o espaço obscuro das ruelas, nas vilas e cidades. Nas casas de seus senhores, além de fiarem o algodão e cuidarem dos afazeres domésticos, especializavam-se em magia e em rituais de encantamento. Longe já se encontravam dos primeiros tempos da conversão. Muitas, através dos casamentos, se deslocavam das aldeias missionárias e se misturavam ao turbilhão urbano nascente. Embora cristãs, não perderam por completo o vínculo com seus referenciais culturais tradicionais, por isso, foram consideradas hereges pelo poder da igreja. ${ }^{63}$

\section{Considerações finais}

Todos esses atores foram obscurecidos por uma historiografia que, desde o século XIX, os tem qualificado como personagens secundários na história do Brasil. Estavam mortos no tempo e surgiam somente através dos des-

\footnotetext{
${ }^{62}$ DANIEL, João, tomo I, 1976, p. 272.

63 Sobre índias hereges: CARVALHO JÚNIOR, Ademir Diniz de, op. cit., 2011.
} 
troços e indícios etnográficos e arqueológicos que atestavam a sua extinção. Quando presentes, eram "impuros", pois haviam rompido com a sincronia de sua "essência" perdida. No entanto, nos subtextos e nas narrativas do poder, demonstram terem sido sujeitos de seu destino, ao se reinventarem a partir de seu enquadramento na lógica de um novo sistema.

Eram "arrependidos por inconstantes", afirmava João Daniel. Antônio Vieira, um século antes, já havia notado o mesmo com singular perspicácia. ${ }^{64}$ Se sua inconstância era sua constância, então sempre foram homens em movimento. Através do uso dos seus talentos, mimetizaram as práticas e técnicas ocidentais em seu benefício. Usando a bela análise de Homi Bhabha sobre o papel da mímica no discurso colonial, entendo que estes nativos também cruzaram as fronteiras da "cultura da enunciação". Para Bhabha, a mímica, através de uma confusão estratégica dos eixos metafóricos e metonímicos, impactou a produção cultural do sentido no discurso colonial. ${ }^{65}$ Tudo indica que as novas práticas foram incorporadas apenas na superfície dos seus gestos. Havia uma luta constante pela liberdade de seus corpos frente à disciplina do trabalho e da moral cristãs. Eles manipularam sempre as regras e imprimiram-lhes um sentido diverso: nos matrimônios, nas liberdades sexuais, nas guerras, no jogo das alianças, nos seus rituais religiosos e nos negócios da colônia.

Não há dúvida de que a nova ordem colonial implantou o caos ao sentido que davam ao seu mundo, criando um impacto profundo em sua cosmologia. Suas referências esvaíram-se, mas com os destroços que sobraram constituíram um novo campo semântico, uma nova rede de significados a partir da qual continuaram teimosamente a existir.

Esta reflexão não teve por objetivo somente identificar e tornar visíveis esses atores marginais. A proposta também foi a de afirmar um marcador identitário genérico que, a princípio, foi tomado como a identificação do aniquilamento desses atores através de sua conquista espiritual e étnica. Marcadores identitários genéricos, como o de índios cristãos, podem mesmo,

\footnotetext{
${ }^{64}$ VIEIRA, Antônio. Sermão do Espírito Santo [1657]. In: PÉCORA, Alcir (org.). Antônio Vieira - Sermões. Tomo I. São Paulo: Hedra, 2003, p. 415-440. Sobre a brilhante análise da visão da inconstância dos brasis por parte de Antônio Vieira no referido sermão, ver: VIVEIROS DE CASTRO, Eduardo. O mamoré e a murta - sobre a inconstância da alma selvagem. In: Idem. $A$ inconstância da alma selvagem e outros ensaios de antropologia. São Paulo: Cosac $\mathcal{E}$ Naify, 2002, p. 183-264.

${ }^{65}$ A mímica, segundo Homi Bahabha, é um modo de discurso e se constitui como um signo de articulação dupla. Ele é uma estratégia de reforma, regulação e disciplina, engendrada pelo poder colonial; mas também é o signo do inapropriado - uma ameaça imanente aos saberes normatizados e aos poderes disciplinares: BHABHA, Homi. Da mímica e do homem. In: Idem. O local da cultura. Belo Horizonte: Editora da UFMG, 1998, p. 129-138.
} 
REVISTA DE HISTÓRIA

SÃO PAULO, N ${ }^{\circ} 168$, p. 69-99,

JANEIRO / JUNHO 2013

como pensam alguns, embotar uma visão mais singular das especificidades étnicas. Mas se partirmos do pressuposto de que os processos de formação étnica são produtos dialógicos e não somente endógenos, é possível aceitar, com base nos vestígios aqui expostos, que através da apropriação de códigos impostos houve uma subversão das tecnologias de poder que objetivavam a sua assimilação e a extinção de suas diferenças.

Considerando as ideias acima, se houve mestiçagem cultural, ela se deu numa dimensão de embates entre significados; se houve prevalência da ordem colonial, ela foi reconfigurada e subvertida no seu uso através de novas formas de adaptação. Assim, é possível pensar numa mestiçagem indígena, mesmo numa chave identitária produzida pelo poder colonial. O cristianismo adotado por esses atores não significou sua conquista espiritual completa, ele foi uma adaptação possível produzida nos interstícios da nova ordem.

\section{Referências bibliográficas}

\section{Fontes impressas}

BETTENDOFF, João Felipe. Crônica da missão dos padres da Companhia de Jesus no Estado do Maranhão. $2^{\text {a }}$. ed. Belém: Fundação Cultural do Pará Tancredo Neves/Secretaria de Estado da Cultura, 1990 [1694-1698].

DANIEL, João. Tesouro descoberto do rio Amazonas. Rio de Janeiro: Anais da Biblioteca Nacional do Rio de Janeiro, 95, v. 1-2 , 1975.

PÉCORA, Alcir (org.). Antônio Vieira - Sermões. Tomos I e II, São Paulo: Hedra, 2003.

\section{Bibliografia}

ALMEIDA, Maria Regina Celestino de. Metamorfoses indígenas - identidade e cultura nas aldeias coloniais do Rio de Janeiro. Rio de Janeiro: Arquivo Nacional, 2003. . Os índios na história do Brasil. Rio de Janeiro: Editora FGV, 2010.

BHABHA, Homi. Da mímica e do homem. In: Idem. O local da cultura. Belo Horizonte: Editora da UFMG, 1998, p. 129-138.

BOCCARA, Guillaume. Poder colonial e etnicidade no Chile: territorialização e reestruturação entre os Mapuche da época colonial. Revista Tempo. Rio de Janeiro: Editora da UFF, n. 23, 2007, p. 56-72.

CARNEIRO DA CUNHA, Manuela (org.). História dos Índios no Brasil. São Paulo: Companhia das Letras, 1992

CARVALHO JÚNIOR, Almir Diniz de. A magia do novo - índios cristãos nas fronteiras da Amazônia colonial. Revue Nuevo Mundo Mundos Nuevos, Debates. École des Hautes Etudes en Sciences Sociales - EHESS, 2011. Disponível em: http:// nuevomundo.revues.org/g2258. Acesso em 29/09/2012. 
Visão do diabo - crenças e rituais ameríndios sob a ótica dos jesuítas na Amazônia colonial - séculos 17 e 18. Amazônia e outros temas: coleção de textos antropológicos. Programa de Pós-Graduação em Antropologia Social. Manaus: Edua, 2010, p. 159-194.

Líderes indígenas no mundo cristão colonial. Canoa do Tempo - Revista do PPGH/UFAM, v. 1, n. 1. Manaus: Edua/Fapeam, 2007, p. 123-150.

Índios cristãos: a conversão dos gentios na Amazônia portuguesa (1653-1769). Tese de doutorado, Unicamp, Campinas, 2005.

CARVALHO JÚNIOR, Almir Diniz de e NORONHA, Nelson Matos de (orgs.). A Amazônia dos viajantes - História e ciência. Manaus: Edua/Ufam, 2011.

CERTEAU, Michel de. A invenção do cotidiano - artes de fazer. Petrópolis: Vozes, 1994.

DOMINGUES, Ângela. Quando os índios eram vassalos: Colonização e relações de poder no norte do Brasil na segunda metade do séc. XVIII. Lisboa: Comissão Nacional para as Comemorações dos Descobrimentos Portugueses, 2000.

EISENBERG, José. As missões jesuíticas e o pensamento político moderno - encontros culturais, aventuras teóricas. Belo Horizonte: Editora da UFMG, 2000.

FERNANDES, Florestan. A função da guerra na sociedade Tupinambá. São Paulo: Editora da USP/Livraria Pioneira Editora, 1970 [1952].

GARCIA, Elisa Frühauf. As diversas formas de ser índio: políticas indígenas e políticas indigenistas no extremo sul da América portuguesa. Rio de Janeiro: Arquivo Nacional, 2009.

MONTEIRO, John Manuel. Tupi, tapuias e historiadores: estudo de história indígena e do indigenismo. Tese de livre docência, Unicamp, Campinas, 2001.

Negros da terra: índios e bandeirantes nas origens de São Paulo. São Paulo: Companhia das Letras, 1994.

MONTERO, Paula. Índios e missionários no Brasil: para uma teoria da mediação cultural. In: Idem (org.). Deus na aldeia. Missionários, índios e mediação cultural. São Paulo: Globo, 2006, p. 31-66.

PERRONE-MOISÉS, Beatriz. Índios livres e índios escravos: os princípios da legislação indigenista do período colonial (séculos XVI e XVIII). In: CARNEIRO DA CUNHA, Manuela (org.). História dos índios no Brasil, 1992.

POUTIGNAT, Philippe \& STREIFF-FENART, Jocelyne, Teorias da etnicidade seguido de Grupos étnicos e suas fronteiras de Fredrik Barth. São Paulo: Editora da Unesp, 1998.

QUEIROZ, Jonas Marçal de e COELHO, Mauro Cezar (orgs.). Amazônia-modernização e conflito. Belém: UFPA/Naea; Macapá: Unifap, 2001.

REIS, Arthur Cezar Ferreira. A conquista espiritual da Amazônia. $2^{\mathrm{a}}$. ed. Manaus: Editora da Universidade do Amazonas/Governo do Estado do Amazonas, 1997.

RESENDE, Maria Leônia Chaves de. Gentios brasílicos - índios coloniais em Minas Gerais setecentista. Tese de doutorado, Unicamp, Campinas, 2003.

SAHLINS, Marshall. Ilhas de história. Rio de Janeiro: Zahar, 1990.

SAMPAIO, Patrícia Maria Melo. "Vossa Excelência mandará o que for servido...": políticas indígenas e indigenistas na Amazônia portuguesa do final do século XVIII. Revista Tempo, vol. 12, n. 23. Rio de Janeiro: Departamento de História UFF, 2007, p. 49-65. 
SPALDING, Karen. The colonial Indian: Past and future research perspectives. Latin American Research Review, 7, n. 1, p. 47-76.

SIDER, Gerald. Identity as history, ethnohistory, ethnogenesis and ethnocide in the Southeastern United States. Identities, 1, n. 1, 1994.

TORRES-LONDOÑO, Fernando. La experiencia religiosa jesuítica y la crónica misionera de Para y Maranhão en el siglo XVII. In: NEGRO, Sandra; MARZAL, Manuel (orgs.). Un reino en la frontera: las misiones jesuíticas en la América colonial. Quito: Abya-Yala, 1999.

VAINFAS, Ronaldo. A heresia dos índios - Catolicismo e rebeldia no Brasil colonial. São Paulo: Companhia das Letras, 1995.

VIVEIROS DE CASTRO, Eduardo e CARNEIRO DA CUNHA, Manuela. A vingança e temporalidade: os Tupinambá. Journal de la Societé des Americanistes, n. 71, 1985, p. 191-217.

VIVEIROS DE CASTRO, Eduardo. O mamoré e a murta - sobre a inconstância da alma selvagem. In: Idem. A inconstância da alma selvagem e outros ensaios de antropologia. São Paulo: Cosac $\mathcal{E}$ Naify, 2002, p. 183-264.

WHITEHEAD, Neil. Etnogeneses and ethnocide in the European occupation of native Surinam, 1499 - 1681. In: HILL, Jonanthan D. History, power and identity. Lancelot, Iowa City: University of Iowa Press, 1996, p. 20-35.

Recebido: 08/11/2012 - Aprovado: 01/04/2013 